\title{
Determination Of The Suspect Of Decency Crime In Police Resort Kudus (Case Study in the PPA Police Kudus)
}

\author{
Bonar Setyantono ${ }^{1}$ and Jawade $\mathrm{Hafidz}^{2}$
}

Abstract. Act No. 17 of 2016 concerning Second Amendment Act No. 23 of 2002 on the Protection of Children into the law on protection of children. The Criminal Code decency criminal acts against children stipulated in the Criminal Code in Chapter XIV of Article 287, Article 289, Article 290, Article 292, Article 293, Article 294, Article 295 and Article 296 of the Criminal Code. Sanction criminal acts of decency against Children in the Child Protection Act provided for in Article 81, 81A and 82, it is as chapter to ensnare AD bin SPT has committed the crime of DSH.

Determination Mechanism Crime Suspect Actor of Decency, a complaint go to the police station, Disposition down unit further women's and children Women and Children Services Unit conducted an investigation. Investigations completed his case to determine whether the elements of a criminal offense are met, if the elements are met and the initial evidence, then the police can determine the suspect's Women and Children Unit subsequently conducted investigation against the suspect to complete the examination of the case file. Barriers or obstacles, namely victims and their families did not immediately report to the police, in providing materially incomplete, the loss of evidence and the suspect fled. Solutions to overcome obstacles or barriers that Police (Policewoman) conduct a personal approach to the victim with the intention of victims give full details, the investigators provide a special place to do the investigation, victims and their families can request legal considerations with the investigator, with the purpose of the case is not protracted and can be immediately handled.Take quick decisions to prevent criminals escaping decency.

Keywords: Determination of the Suspect; Decency Criminal Acts and Children.

\section{Introduction}

Decency Criminal Acts can generally be defined as the act has to do with norms of decency, but in terms of the crime of obscene important and needs to be seen is the extent to which the violation of decency (sexual misconduct) was committed.

The definition of the crime of morality in general is all the actions undertaken to obtain sexual pleasure at once disturbing honor decency. In the case of the criminal act of decency actually no definition or understanding that explains the meaning of the criminal act of decency. In the Criminal Code offense of decency crime under Article 281-283 of the Criminal Code, the elements of the crime of decency as stipulated in Article 281 of the Criminal Code is a subjective element. Namely "intentionally" and an objective element, namely the "whosoever", "corrupting morals" and "public".

\footnotetext{
${ }^{1}$ Student of Master of Law, Universitas Islam Sultan Agung Semarang and Police members of Polres Kudus, email: setyantonobonar@yahoo.com,

${ }^{2}$ Faculty of Law, Universitas Islam Sultan Agung (Unissula) Semarang
} 
Subjective unsure state Article 281 of the Criminal Code is an element of intentionally (opzettelijk) which includes elements such as, undermine morality and public.

The public generally assess morality as a form of deviation / sexual crimes, because it was contrary to the laws and norms of life in the community. Decency offense stipulated in Chapter XIV of book II of the Criminal Code under the title "crimes against morality" which began with the Article 281 to Article 296 of the Criminal Code. Article 281 of the Criminal Code states that:

Threatened with imprisonment of two years and eight months or a maximum fine of four thousand five hundred rupiah:

- Whoever intentionally violated ethics in public;

- Whoever intentionally violating decency in front of other people who were there not because own desire.

Elements contained in Article 281 of the Criminal Code as mentioned above is very clear, that the element of "whoever" and the element of "intentionally". Elements whoever is written in Article 281 of the Criminal Code applies to everyone without exception, and elements purposely be meant that the person who committed the crime of wanton intentionally, the offender committed the crime of wanton knowingly and perpetrators know what it is doing is against the law as stipulated in the legislation.

Moreover, decency criminal acts committed by an adult against Children. In general terms kids are a man or women who are immature or have not experienced of puberty. ${ }^{3}$ Policies in the positive law governing crimes against children decency prevailing in Indonesia, among others, as set in Article 281 of the Criminal Code 296, Act No. 11 of 2012 on the Criminal Justice System of Child, Act No. 17 of 2016 concerning the Stipulation of Government Regulation in Lieu of Act No. 1 of 2016 concerning Second Amendment Act No. 23 of 2001 on Protection of Children Being Law, Act No. 35 of 2014 on the Amendment of Act No. 23 of 2002 on Protection of Children and Act No. No. 19 of 2016 About Amendment Act No. 112008 on Information and Electronic Transactions.

The government has sought to prevent and protect Children against sexual crimes by issuing Act No. 17 of 2016 concerning the Stipulation of Government Regulation in Lieu of Act No. 1 Of 2016 About the Second Amendment to Act No. 23 of 2002 on the Protection of Children Become Act.

In the case of sexual crimes perpetrators still people close to the victim, so that sexual crimes are still happening, in general, parents protect their children from the outside of the crime, but what happens sexual crimes committed by people close to the victim, such as a neighbor even there your relationship with victim. Necessary to attempt the prevention of sexual crimes against children for the future, so that the protection of children against sexual crimes can be pleasant.

Based on the description as mentioned above, the authors are interested in conducting research thesis entitled "Determination Of The Suspect Of Decency Crime In Police Resort Kudus". Issues that will be examined in this study is how the criminal

\footnotetext{
3 Mohammad Taufik Makarao, Weny Bukamo, dan Syaiful Azri, 2013, Hukum Perlindungan Anak dan Penghapusan Kekerasan dalam Rumah Tangga, Rineka Cipta, Jakarta, p. 15.
} 
law policy positively regulates criminal offenses against children decency?, How is the determination of the criminal suspect decency? and whether the problems / obstacles that arise in determining a suspect in a criminal act morals of minors in the Kudus Police and the solution?

\section{Research methods}

The method used in this research is empirical jurisdiction, Dyah Ochtorina Susanti and $A^{\prime}$ an Efendi, stated that the juridical empirical include research into the identification of law (common law) and research on the effectiveness of the law. ${ }^{4}$

Based on empirical research method that is juridical, the specifications in this research using descriptive analysis. Data will be used in this study are primary data and secondary data.

This research use qualitative data analysis, that the results of this study will elaborate on in the form of a regular sentence, cascading logical, non-overlapping and effective so it is easy to understand and in interpretation.

\section{Results and Discussion}

\subsection{Criminal Law Policy Positively Regulates The Crime Of Decency Against Children}

Under Article 1 point 14 The Book of Criminal Law (Criminal Code), states that the suspect is a person because of his actions or conditions based on preliminary evidence reasonably suspected as criminals. Investigations conducted by the investigator based on Article 1 (2) The Book of Criminal Law which states that "the investigation is a series of actions the investigator in the case and in the manner set forth in this law to search for and collect evidence with evidence that shed light on crime that happened and in order to find the suspect ". Investigation Under Article 1 (2), as mentioned above, there are two things that can be done by the investigator, which collects the evidence and find the suspect.

The investigation authority is the authority of the Police Investigators this case pursuant to Act No. 2 of 2002 on the Indonesian police. Forms of criminal acts immoral committed by adults against children such as providing exposure to indecent from the genitals to a child, displaying pornography to a child, sexual intercourse against children, physical contact with the genitals of children (except in the context of nonspecific sexual such as medical examination), look at the child's genitals without physical contact (except in a non-sexual context such as medical examination), or using a child to produce child pornography. ${ }^{5}$

Form positive criminal law policy that regulates the crime of decency against children, the Government stated Act No. 11 of 2012 on the Criminal Justice System Child, Act No. 35 of 2014 on the Amendment of Act No. 23 of 2002 on the Protection of Children then amended again by Act No. 17 of 2016 on Stipulation of Government Regulation in

\footnotetext{
${ }^{4}$ Dyah Ochtorina Susanti and A'an Efendi, 2014, Penelitian Hukum (Legal Research) ,Sinar Grafika, Jakarta, p. 18.

${ }^{5}$ Interview with Sri Sudarmi, Head of the Women and Children Service Unit of the KudusPolice, dated 28 November 2018
} 
Lieu of Act No. 1 of 2016 on Second Amendment to Act No. 23 of 2001 on the Protection of Children Being Law (hereinafter written Child Protection Act). It is a form of government in providing protection against Children, for Children as the next generation of the nation and the State.

In the Criminal Code of decency against Children criminal offense as stipulated in Chapter XIV Article 287, Article 289, Article 290, Article 292, Article 293, Article 294, Article 295 and Article 296 of the Criminal Code. Article 76D Child Protection Act states that everyone prohibited from engaging in violence or threats of violence to force the Child had intercourse with her or with other people. In Article 81 paragraph (2) and (3) the Child Protection Act states that:

(2) The provision crime referred to in paragraph (1) shall also apply to any person who deliberately ruse, a series of lies, or induce Child sexual intercourse with him or with anyone else.

Paragraph (3) If the crime referred to in paragraph (1) shall be done by parents, guardians, those who have a family relationship, nannies, educators, staff, personnel who handle child protection, or carried out by more than one people together, the punishment of $1 / 3$ (one third) of the criminal sanction as referred to in paragraph (1). In this study the authors will examine the criminal acts of decency against Children undertaken by AD bin SPT against DSH bin AK. The perpetrator charged under Article 81 paragraph (2) and (3) of the Act Protection of the Child, which states that:

The procedure for investigation suspect was examined by investigators still have the right, the right of suspects to get immediate examination by the investigator. Meaning of "soon" is not described in the legislation, but of understanding the language might "soon as possible" or "now" without waiting longer. ${ }^{6}$

\subsection{Determination Mechanism Suspect of Decency Crime Actor}

Suspect examination upfront way in terms of judicial investigators, as follows: ${ }^{7}$

- Suspect be delivered answer to the investigator, given without any pressure from anyone with any form, as well as Article 117 of the Criminal Procedure Code.

- Investigators noted carefully every description Suspect Investigators noted: ${ }^{8}$

- In accordance with a series of words that are used suspects. Description suspects as contemplated in the above provisions: Recorded in the Minutes of Investigation by Investigator; When finished, asked or requested consent from the suspect about the truth of the contents of the Investigation Report.

- If the suspect who was about to be examined resides outside the jurisdiction of Inquiry, the Investigator that can impose checks to the investigator that authorities in the area of residence suspect or delegating investigation, in this case it under Article 119 Criminal Procedure Code, which states that:

In the case of a suspect or a witness who should be heard resident or residing outside the jurisdiction investigator who runs the investigation, examination of

\footnotetext{
${ }^{6}$ Ibid, p. 135.

${ }^{7}$ Ibid, p. 137-138.

8 Ibid, p. 138.
} 
suspects or witnesses can be charged to the investigator at the residence or place of residence or the suspect and the witness.

- Suspects who can not attend facing investigators do in the house of suspect, as the provisions of Article 113 of the Criminal Procedure Code which states that if a suspect or witnesses called to give fair and reasonable grounds that he can not come to the investigator conducting the inspection, the investigator came to his place. The meaning of Article 113 of the Criminal Procedure Code, which investigators suspect came to the house to check on the residence of the suspect, this is done by investigators when suspects reasons can not appear before the investigator appropriate and reasonable.

In this study using progressive legal theory, it is the law in the spirit of doing the best for the community, nation, and state. Progressive law requires an honest man. Venture out of the order is a way of finding and freeing, because for Prof. Satjipto Raharjo, progressive legal science is the type of science that is always restless searching and liberation.

In the case of the determination of the suspect would adopt a progressive law theory of law is always evolving in the community, sanctions or penalties for perpetrators of criminal acts immoral can be developed, it is tailored to the cultural progress in society. Penalties for perpetrators of criminal acts of decency against Children in the Child Protection Act is very clear sanctions as samples in this research that Article 81 of the Child Protection Act. In this research actors in meshes with Article 81 paragraph (2) and (3) of the Law on Child Protection, as mentioned above.

Application of Article 81 paragraph (2) and (3) to catch the offender decency AD bin SPT very precise. It is a form of the State to protect the rights of the Child, as mentioned in the judgment in the Child Protection Act which states that the State ensure children's rights to survival, growth and development, as well as protection from violence and discrimination as contained in the Constitution of the Republic of Indonesia 1945,

The fundamental barriers that exist in the legal protection of the moral evil is the lack of a common point of view to do and put the victim in a position of truth. Given position victims as those who need legal protection that interests have been harmed can be restored. However, in practice the parties has not run optimally.

\subsection{Constraints / Obstacles That Appear In Establishing Decency Crime Suspect of Children Under Age At Kudus Police And Solutions}

Barriers or obstacles that arise are as follows: ${ }^{9}$

- Victims and their families are not immediately reported to the police

Shortly after the incident the victim and her family did not immediately report to the police station nearby, because the victim's family believe that a criminal offense which meninpa son is regarded as a disgrace to his extended family, shame about the neighbors and the psyche of children who are victims too shocked and still

\footnotetext{
9 Interview with Agus Supriyadi Siswanto, Head of Criminal of the Kudus Police, dated 27 November 2018.
} 
traumatized, basically it is used as a reason the victim and his family was not immediately reported.

- In providing materially incomplete

Victims in providing information is not complete and detailed to investigators, the victim feels embarrassed to testify the truth, there are those who covered up making it difficult for investigators to make Dossiers. Description Incomplete would complicate investigators in determining the suspect. Sexual discuss before others could embarrass the victim, it is this which makes the victim concealing information.

- The loss of evidence

The loss of evidence, because the victims and their families did not immediately report to the police, so that the case dragged on, too much consideration so that after taking the decision to report to the police the evidence that can be used as evidence permjulaan to establish the suspect is not there, the investigators just get information only of the victims. Victim's family (parents) too much consideration in making a decision, this is because the victim is his daughter, parents feel guilty because they thought had failed in educating children. In general, parents are too old to think of her daughter receiving the disaster that were never imagined before.

- The suspect fled

Victims and their families late reporting to the police so that the perpetrators escape, in order to avoid legal proceedings, will therefore be very difficult for investigators to make arrests of perpetrators, and that clearly adds to the burden of the Investigator, for offenders to escape so that the police need to find out where the perpetrator abduct themselves where, police need time to track down the perpetrators.

Some obstacles as mentioned above, the authors provide a solution or a way out as follows:

- Police appealed to the victims, their families and the public to immediately report if there are family members, children and siblings who are victims of criminal acts of decency. With the report does not mean opening the family disgrace, but to make a police report, it is helping police in exposing and processing the criminal law of decency. Police (Policewoman) conduct a personal approach to the victim with the intention of victims give full details.

- Preferably victim testified as complete, so that no cover-up because, the investigators provide a special place to perform Investigation on crime victims Decency, which is a special room only Investigators Women, victims and their families who mendapinginya, so that the victim does not feel embarrassed when questioned by investigators.

- Immediately report, the evidence that can be used as preliminary evidence to determine the suspect is still there, should take that into consideration, but not for too long.

- Take quick decisions to prevent criminals escaping decency. The police can immediately make an arrest in the presence of 2 starters plus evidence from the victim, then the police can immediately immediately arresting the perpetrators. 2 
(two) tools become very important preliminary evidence for investigators, because to determine the suspect and that evidence will be used as evidence in court.

\section{Closing}

\subsection{Conclusion}

- Positive Criminal Law Policy Set Decency Crime Against Children The government issued the Law of the Republic of Indonesia No. 17 of 2016 About Determination of Government Regulation in Lieu of Act No. 1 of 2016 on the second amendment to Act No. 23 of 2002 on the Protection of Children Become Act and the Criminal Code.

- Determination Mechanism Decency Crime Suspect Actor The determination of the suspect is as follows:

- Their complaints into the police station, Disposition down to Women and Children Services Unit;

- Women and Children Services Unit conducted an investigation to call witnesses who allegedly know the incidence of crime;

- Investigations completed his case;

- Women and Children Service Unit subsequently conducted investigation against the suspect to complete the case file of the investigation;

- If the perpetrator was caught hand, it can be immediately set as a suspect;

\subsection{Suggestion}

- To the police officers, routinely disseminate to the public about the importance of direct handling of cases of criminal acts of decency, with the aim of community response in case of criminal acts surrounding decency.

- To the Community, the victim and the victim's parents, immediately report to the police if their children or relatives become crime victims of decency, so that the perpetrators can be arrested and prosecuted for the realization of justice for all Indonesian people, as stated in the $5^{\text {th }}$ precepts of Pancasila.

- To people, so obey immediately applicable legal requirements, comply with the norms prevailing in society, and is expected to increase the faith community with the goal of abstinence can not easily provoked and tempted by something sexual nature.

\section{Bibliography}

\section{Book}

[1] Bambang Sunggono, 1997, Metode penelitian Hukum,Raja Grafindo Persada, Depok

[2] Dyah Ochtorina Susanti dan A'an Efendi, 2014, Penelitian Hukum (Legal Research) ,Sinar Grafika, Jakarta 
[3] Mohammad Taufik Makarao, Weny Bukamo, dan Syaiful Azri, 2013, Hukum Perlindungan Anak dan Penghapusan Kekerasan dalam Rumah Tangga, Rineka Cipta, Jakarta

\section{Legislation}

[1] Constitution of the Republic of Indonesia 1945;

[2] The Draft of Penal Code;

[3] The Code of Criminal Procedure;

[4] Act No. 35 of 2014 on the Amendment of Act No. 23 of 2002 on the Protection of Children;

[5] Act No. 11 of 2012 on Child Criminal Justice System;

[6] Act No. 17 of 2016 concerning the Stipulation of Government Regulation in Lieu of Act No. 1 of 2016 concerning Second Amendment Act No. 23 of 2001 on Protection of Children Being The Law. 